\title{
ANALISIS BIAYA DAN PENDAPATAN USAHATANI CABAI RAWIT DI KECAMATAN CIGALONTANG KABUPATEN TASIKMALAYA
}

\section{ANALYSIS OF COST AND INCOME OF CAYENNE PEPPER FARMING IN CIGALONTANG SUBDISTRICT TASIKMALAYA DISTRICT}

\section{Anisa Puspitasari}

Fakultas Pertanian Universitas Galuh

Email: nisapuspita253@gmail.com

(Diterima 21-07-2020; Disetujui 29-07-2020)

\begin{abstract}
ABSTRAK
Cabai merupakan salah satu komoditas sayuran unggulan nasional dan memiliki nilai ekonomis cukup tinggi. Kebutuhan cabai rawit merah terus meningkat setiap tahun sejalan dengan meningkatnya jumlah penduduk dan berkembangnya industri yang membutuhkan bahan baku cabai rawit. Tujuan penelitian kali ini untuk menganalisis biaya, pendapatan dan efisiensi usahatani cabai rawit di Kecamatan Cigalontang. Responden penelitian sebanyak 30 petani. Hasil penelitian menunjukkan penerimaan usahatani cabai rawit di Kecamatan Cigalontang sebesar Rp 130.733.510/ha/th, biaya tunai Rp 69.582.450/ha/th, dan biaya total Rp 73.765.150. Usahatani cabai rawit menguntungkan dilihat dari pendapatan sebesar Rp 61.151.060. Efisiensi usahatani cabai rawit dari biaya tunai sebesar 1,88 dan dari biaya total sebesar 1,77.
\end{abstract}

Kata kunci: Biaya, Pendapatan, Efisiensi, Cabai rawit

\section{ABSTRACT}

Chili is one of the leading national vegetable commodities and has quite high economic value. The need for red cayenne pepper continues to increase every year in line with the increasing population and the development of industries that need raw cayenne pepper. The purpose of this study is to analyze the cost, income and efficiency of cayenne pepper farming in Cigalontang District. Research respondents were 30 farmers. The results showed the revenue of cayenne pepper farming in Cigalontang Subdistrict amounted to $R p$ 130,733,510/ha/year, cash costs $R p$ 69,582,450/ha/year, and a total cost of $R p$ 73,765,150. The cayenne pepper farming is advantageous from the income of $R p$ 61,151,060. The efficiency of cayenne farming from cash costs is 1.88 and from a total cost of 1.77 .

Keywords: Cost, Income, Efficiency, Cayenne Pepper

\section{PENDAHULUAN}

Indonesia memiliki sumber daya alam yang cukup besar, potensi tersebut seharusnya dimanfaatkan secara optimal untuk meningkatkan perekonomian dan kesejahteraan masyarakat. Sektor pertanian merupakan salah satu sektor yang cukup berpengaruh terhadap pertumbuhan ekonomi di Indonesia. Sektor ini memiliki share sebesar 14,9\% pada tahun 2015-2018 terhadap PDB nasional (BPS, 2018).

Pendapatan masyarakat Indonesia didominasi dari sektor pertanian, sehingga sektor pertanian di Indonesia harus terus dikembangkan untuk 
keberlangsungan hidup masyarakat. Pembangunan pertanian juga dihadapkan pada perubahan lingkungan strategis, baik domestik maupun internasional yang dinamis, sehingga menuntut produk pertanian yang mampu berdaya saing di pasar global. Sebagai upaya peningkatan daya saing dan nilai tambah produk pertanian Indonesia, dibutuhkan efisiensi dalam sistem produksi, pengolahan dan pengendalian mutu serta kesinambungan produk yang didukung dengan upaya produksi dan pemasaran untuk peningkatan daya saing tersebut. Sub sektor pertanian meliputi, perkebunan, peternakan, perikanan, hortikultura, dan tanaman pangan (Deptan, 2012).

Cabai rawit (Capsicum frutescens L.) merupakan salah satu tanaman hortikultura dari famili Solanaceae yang tidak saja memiliki nilai ekonomi tinggi, tetapi juga karena buahnya yang memiliki kombinasi warna, rasa, dan nilai nutrisi yang lengkap (Kouassi et al, 2012). Cahyono (2003) mengemukakan bahwa tanaman ini termasuk tanaman semusim atau tanaman berumur pendek yang tumbuh sebagai perdu atau semak, dengan tinggi tanaman dapat mencapai $1,5 \mathrm{~m}$.

Menurut Rahmat \& Nirmala (2011), produksi buah dipengaruhi oleh tinggi tanaman (92\%), diameter buah (89\%), dan panjang buah (78\%), dengan demikian, semakin tinggi tanaman maka produksi buah akan semakin meningkat. Ketika produksi meningkat, maka mutu cabai rawit harus dipertahankan. Karakteristik yang menonjol pada cabai rawit yaitu zat capsaicin yang membuat rasa pedas. Selain itu, yang tidak kalah penting adalah tekstur dan warna dari cabai rawit. Cabai mengandung 0,1 -1\% rasa pedas, yang disebabkan oleh kandungan zat capsaicin (Cahyono, 2003).

Cabai merupakan komoditas agribisnis yang besar pengaruhnya terhadap dinamika perokonomian nasional sehingga dimasukkan dalam jajaran komoditas penyumbang inflasi yang terjadi setiap tahun. Angka inflasi tahun 2010 sebesar 6,96 persen dan jenis bahan makanan yang memberikan andil besar dalam inflasi antara lain sebesar 1,29 persen, cabai merah sebesar 0,32 persen, dan cabai rawit sebesar 0,22 persen (BPS, 2018). Hal ini karena produk cabai digunakan dalam berbagai produk pangan baik olahan masakan tradisional maupun modern. Hampir seluruh menu masakan di Indonesia menggunakan cabai. Selain itu, cabai 
tidak dapat disubstitusi oleh komoditas lain.

Cabai merupakan salah satu komoditas sayuran unggulan nasional dan memiliki nilai ekonomis cukup tinggi. Kebutuhan cabai rawit merah terus meningkat setiap tahun sejalan dengan meningkatnya jumlah penduduk dan berkembangnya industri yang membutuhkan bahan baku cabai rawit merah. Selain itu, cabai tidak dapat disubstitusi oleh komoditas lain, sehingga bila terjadi ketidakseimbangan antara produksi dan serapan pasar pasti akan terjadi fluktuasi harga. Salah satu faktor yang menjadi penyebab terjadinya ketidakseimbangan tersebut yaitu pola produksi (adanya on season dan off season) dan pola tanam yang tidak terencana dan tidak terkoordinasi antar tiap kabupaten sentra produksi cabai rawit merah sehingga petani-petani cabai rawit memperoleh pendapatan yang fluktuatif sehingga pendapatan menjadi tidak pasti.

Cabai merupakan komoditas potensial yang memiliki nilai ekonomi tinggi dan berpotensi untuk terus dikembangkan. Dirjen Hortikultura (2015) menyatakan beberapa alasan penting dalam pengembangan komoditas cabai, antara lain merupakan komoditas unggulan bernilai ekonomi tinggi, banyak digunakan untuk konsumsi rumah tangga (80\%) maupun keperluan industri pengolahan makanan (20\%). (Cahyono, 2013) melaporkan bahwa cabai memiliki aktivitas antioksidan, kandungan fenol dan capsaicinoid yang tinggi.

Cabai adalah komoditas sayuran penting yang dibudidayakan dalam pemenuhan kebutuhan gizi masyarakat Indonesia, baik sebagai komoditas yang dikonsumsi di dalam negeri dan ekspor. Jawa Barat adalah salah satu dari beberapa provinsi di Indonesia yang menjadi produsen cabai yang menyebar di beberapa Kabupaten yakni Ciamis, Tasikmalaya, Bandung, Garut, Sukabumi, Cianjur dan Bogor. Menurut Kustiari, dkk (2009), faktor-faktor yang mempengaruhi fluktuasi harga di pasar eceran, yaitu faktor yang mempengaruhi sisi permintaan dan faktor yang mempengaruhi sisi penawaran. Dapat dijelaskan bahwa kadang-kadang keseimbangan harga terjadi pada kondisi jumlah yang ditawarkan relatif jauh lebih sedikit dibandingkan dengan jumlah yang diminta. Hal inilah yang mengakibatkan harga akan sangat tinggi. Demikian pula terjadi sebaliknya sehingga harga sangat rendah. 
Menurut Rahim dan Hastuti (2008), pendapatan usahatani adalah selisih penerimaan dari hasil usahatani dengan semua biaya selama proses produksi (biaya usahatani). Biaya usahatani tersebut merupakan semua nilai dari korbanan ekonomis yang dikeluarkan oleh produsen (petani) dalam mengelola usahataninya untuk mendapatkan hasil yang maksimal. Biaya usahatani diklasifikasikan menjadi dua yaitu biaya tetap (fixed cost) dan biaya tidak tetap (variable cost). Biaya tetap umumnya diartikan sebagai biaya yang relatif tetap jumlahnya dan terus dikeluarkan walaupun output yang diperoleh banyak atau sedikit, seperti: pajak, penyusutan alat, gaji karyawan, sewa lahan, alat pertanian dan sebagainya, sehingga biaya ini dikatakan biaya yang tidak dipengaruhi oleh besarnya produksi komoditas pertanian. Biaya tidak tetap merupakan biaya yang besar kecilnya dipengaruhi oleh hasil produksi komoditas pertanian, seperti: biaya untuk saprodi (sarana produksi komoditas pertanian), sehingga biaya ini diartikan pula sebagai biaya yang sifatnya berubahubah sesuai dengan besarnya produksi komoditas pertanian yang diperoleh. Jika menginginkan produksi tinggi maka faktor-faktor produksi seperti tenaga kerja perlu ditambah, pupuk juga ditambah dan sebagainya.

Kabupaten Tasikmalaya merupakan salah satu sentra produksi aneka cabai di Jawa Barat. Sayuran yang teridentifikasi sebagai komoditas unggulan di Kabupaten Tasikmalaya salah satunya cabai rawit. Salah satu sentra produksi cabai di Kabupaten Tasikmalaya adalah di Kecamatan Cigalontang. Kecamatan Cigalontang adalah salah satu kecamatan yang ada di Kabupaten Tasikmalaya, dengan luas wilayah $12.626,19$ ha dengan ketinggian 700 meter di atas permukaan laut (mdpl).

Cabai rawit dapat tumbuh dengan baik di dataran rendah hingga ketinggian 1.200 meter dpl, namun di dataran tinggi cabai bisa tumbuh tapi produksinya tidak maksimal. Sehingga cabai rawit sangat cocok tumbuh pada ketinggian yang sedang. Wilayah Kecamatan Cigalontang dilihat dari topografinya merupakan daerah dengan ketinggian tempat sekitar 500-700 mdpl. Berdasarkan ketinggian tempat tersebut maka cabai merah sangat cocok dibudidayakan karena tinggi kelembabannya tidak terlalu tinggi (BPS, 2019).

Permasalahan pada cabang usahatani cabai rawit di Kecamatan Cigalontang dapat didekati dari 
produktivitas tanaman, dimana peningkatan produktivitas cabai rawit dapat dilakukan dengan meningkatkan produksinya. Meskipun keadaan geografis yang dimilik oleh Kecamatan Cigalontag sangat mendukung dalam pertumbuhan cabai rawit, tapi tidak serta merta meningkatkan produksi dari usahatani cabai rawit yang dilakukan petani di Kecamatan Cigalontang. Hal ini dikarenakan peningkatan produksi tidak hanya dipengaruhi oleh kondisi tanah yang subur saja. Menurut Rahmat dan Nurmala (2011), dalam peningkatan produksi yang ditempuh dengan usaha penanaman varietas hibrida (Unggul), penggunaan pupuk dan pestisida yang berimbang serta penanganan pascapanen yang tepat.

Produktivitas yang tidak optimal diduga dapat mempengaruhi kondisi pendapatan petani cabai rawit. Oleh karena itu, untuk melihat dari adanya produktivitas yang tidak optimal tersebut, maka perlu dilakukan suatu analisis terhadap pendapatan petani cabai rawit, dengan tujuan sejauh mana kegiatan usahatani cabai rawit memberi keuntungan bagi petani di Kecamatan Cigalontang.

Dari uraian tersebut maka usahatani cabai rawit mengindikasikan rendahnya pendapatan usahatani cabai rawit yang diakibatkan oleh tingkat produksi dan harga cabai rawit tersebut. Berbagai risiko usahatani cabai berdampak pada tingkat pendapatan petani cabai rawit. Pendapatan petani cabai rawit menjadi masalah yang penting, dimana pendapatan usahatani cabai rawit tidak menentu karena tingkat produksi dan ketidakpastian harga yang dihadapi oleh petani. Seiring dengan hal tersebut, terdapat hubungan antara risiko yang dihadapi petani dengan pendapatan usahatani cabai rawit.

Berdasarkan uraian di atas, maka dilakukan penelitian untuk menganalisis biaya, pendapatan dan efisiensi usahatani cabai rawit di Kecamatan Cigalontang.

\section{METODE PENELITIAN}

Penelitian dilakukan di Kecamatan Cigalontang Kabupaten Tasikmalaya, Provinsi Jawa Barat. Penentuan lokasi penelitian dilakukan secara sengaja (purposive) berdasarkan pertimbangan bahwa daerah tersebut merupakan salah satu sentra produksi cabai rawit di Kabupaten Tasikmalaya. Penelitian dilakukan pada bulan Juni-September 2019.

Data yang digunakan adalah data primer dan data sekunder. Data primer 
diperoleh dengan melakukan observasi langsung melalui pembagian kuesioner yang telah disiapkan dengan teknik wawancara kepada petani cabai rawit. Petani yang dijadikan responden dalam penelitian ini adalah petani cabai yang membudidayakan cabai rawit merah di Kecamatan Cigalontang.

Responden ditentukan secara simple random sampling sebanyak 30 petani cabai rawit di Kecamatan Cigalontang.

Untuk menganalisis data dalam penelitian ini maka digunakan analisis deskriptif kuantitatif untuk mengetahui permasalahan tentang berapa besar pendapatan petani cabai rawit Kecamatan Ciaglontang menguntungkan petani maka digunakan rumus pendapatan dan analisis R/C. Pendapatan usahatani adalah selisih antara penerimaan dengan biaya yang dihitung dengan persamaan berikut:

$$
\mathrm{Pd}=\mathrm{TR}-\mathrm{TC}
$$

\section{Dimana:}

$\mathrm{Pd}=$ Pendapatan

$\mathrm{TR}=$ Total Penerimaan

$\mathrm{TC}=$ Total Biaya

Analisis $\mathrm{R} / \mathrm{C}$ ratio adalah singkatan dari Return Cost Ratio. Atau dikenal sebagai perbandingan (nisbah) antara pemerintah dan biaya. Secara matematik, hal ini dapat dituliskan sebagai berikut:

$$
\text { Rasio keuntungan biaya }(\pi / \mathrm{C})=\frac{\pi i}{C i}
$$

Keterangan:

$\pi \mathrm{i}=$ Penerimaan

$\mathrm{Ci}=$ biaya

Apabila $\pi / \mathrm{C}$ lebih dari satu $(\pi / \mathrm{C}$ $>1$ ), maka usaha tersebut efisien, dan apabila $\pi / \mathrm{C}$ kurang dari satu $(\pi / \mathrm{C}<1)$, maka usaha tersebut tidak efisien.

\section{HASIL DAN PEMBAHASAN}

Jumlah tanggungan yang relatif besar akan menekan biaya produksi yang dibayarkan petani akan kecil. Dengan penambahan tenaga kerja dalam keluarga akan menambah pendapatan yang diterima petani. Keseriusan dalam penerapan teknologi juga akan semakin baik apabila diusahakan oleh anggota keluarga bila dibandingkan dengan tenaga kerja borongan (luar keluarga), (Yulizar, 2015).

Kelompok usia tertinggi terdapat pada usia 31-40 tahun sebanyak 10 petani atau sebesar 33,33 persen. Kelompok usia ini termasuk ke dalam usia produktif atau usia kerja. Di kecamatan ini juga terdapat petani dengan kelompok usia $\geq 61$ atau sebesar 26,67 persen. Hal ini menggambarkan bahwa petani yang berusia relatif tua ( $\leq 61$ tahun) juga masih mampu untuk mengelola lahan untuk kebutuhan hidup. 
Petani responden memiliki tingkat pendidikan yang cukup tinggi karena ada beberapa petani yang sudah menyelesaikan pendidikan di perguruan tinggi. Persentase pendidikan petani responden tertinggi pada penelitian ini adalah sekolah dasar pada umumnya petani memiliki tingkat pendidikan sekolah dasar sebesar 43,33 persen, sedangkan persentase terendah adalah tingkat perguruan tinggi yaitu 6,67 persen.

Rata-rata luas lahan yang digarap petani responden sebesar 0,649 hektar dengan luas lahan terkecil adalah 0,1 hektar dan luas terbesar adalah 4 hektar. Status kepemilikan lahan petani responden sebagian besar merupakan milik sendiri dengan persentase sebesar 90 persen dan 10 persen merupakan lahan sewa.

Pengalaman petani antara 0-5 sebanyak $26,67 \%$ dan petani yang memiliki pengalaman cukup lama adalah 6-10 tahun dengan persentase 40\%. Pengalaman petani turut mempengaruhi kemampuan petani dalam menerima inovasi baru dalam upaya peningkatan produksi.

Pengalaman dalam berusaha juga menentukan keberhasilan suatu usahatani. Petani dengan pengalaman kerja yang lebih lama akan lebih mudah mengambil keputusan yang baik pada saat yang tepat. Selain itu, pengalaman seseorang merupakan indikator terhadap kemampuan dalam mengembangkan usahataninya. Dengan pengalaman yang lebih lama, pengalokasian sumber daya yang dimiliki akan lebih efektif. (Yulizar, 2015).

Rata-rata tanggungan keluarga petani responden adalah 3 jiwa. Dengan jumlah tanggungan yang besar, pencurahan tenaga kerja dalam keluarga relatif lebih besar pula terhadap kegiatan usahatani cabai di daerah penelitian. Hal ini penggunaan pencurahan tenaga kerja luar keluarga (LK) harus diprioritaskan, dengan alasan biaya yang dibayar tenaga kerja upahan atau bersifat borongan.

Jumlah tanggungan atau jumlah orang yang menjadi tanggung jawab petani terhadap kelangsungan hidup dan pendidikannya juga mempengaruhi pendapatan dan pengeluaran keluarga petani. Jumlah tanggungan juga merupakan aset tersendiri bagi keluarga petani. Dengan jumlah tanggungan yang besar maka petani akan memiliki tenaga kerja dalam keluarga yang lebih besar pula. Hal ini akan berpengaruh terhadap biaya yang sebenarnya termasuk dalam penerimaan keluarga tani. 
Analisis pendapatan usahatani penting untuk diketahui, untuk memberikan gambaran mengenai keuntungan dari kegiatan usahatani. Analisis pendapatan usaha tani meliputi analisis pendapatan atas biaya tunai dan analisis pendapatan atas biaya total.

Analisis pendapatan usaha tani penting untuk diketahui untuk memberikan gambaran mengenai keuntungan dari kegiatan usahatani. Pendapatan merupakan selisih antara penerimaan total dengan biaya total. Penerimaan total dipengaruhi oleh jumlah produksi yang dihasilkan dan tingkat harga yang berlaku pada saat produk tersebut dijual.

Penerimaan yang diperoleh oleh petani responden dari produktivitas ratarata adalah sebesar $49.333 \mathrm{~kg}$ per ha, dengan harga rata-rata yang diperoleh dari januari-juni adalah Rp 26.500 per kg, sehingga diperoleh penerimaan sebesar Rp. 130.733.510.

Tabel 1. Rata-rata Penerimaan usahatani Cabai Rawit

\begin{tabular}{|c|c|c|c|}
\hline No & Uraian & Satuan & Nilai \\
\hline 1 & Produktivitas & $\mathrm{kg} / \mathrm{ha}$ & $4.933,34$ \\
\hline 2 & Harga & $\mathrm{Rp} / \mathrm{ha}$ & 26.500 \\
\hline 3 & Penerimaan & $\mathrm{Rp}$ & 130.733 .510 \\
\hline
\end{tabular}

seluruh biaya yang dikeluarkan oleh petani dalam usahatani cabai rawit, biaya usahatani pada penelitian ini terbagi menjadi dua. Biaya usahatani yang tergolong pada biaya tunai dan biaya yang diperhitungkan. Dapat dilihat pada Tabel 2.

Biaya tunai pada suatu usahatani lebih tinggi dibandingkan dengan biaya yang diperhitungkan. Berdasarkan Tabel 2 diperoleh biaya tunai sebesar Rp 69.582.450. Total biaya yang diperoleh pada usahatani cabai rawit ini adalah $\mathrm{Rp}$ 73.765.150. Dari hasil penelitian ini dapat dilihat bahwa biaya yang paling tinggi diperoleh dalam usahatani cabai rawit di Kecamatan Cigalontang adalah biaya tenaga kerja luar keluarga (TKLK) yaitu sebesar 40,60 persen dan biaya yang paling kecil adalah penyusutan yaitu 0,08 persen.

Benih yang digunakan pada penelitian kali ini adalah jenis varietas si madun, biaya yang dikeluarkan untuk benih adalah sebesar Rp 2.024.000 atau sebesar 2,74 persen dari total biaya yang dikeluarkan. 
Tabel 2. Komponen Biaya Usaha Tani Cabai Rawit di Kecamatan Cigalontang

\begin{tabular}{|c|c|c|c|c|c|}
\hline \multirow{2}{*}{$\frac{\text { No }}{\text { A }}$} & Komponen & Jumlah & \multirow[t]{2}{*}{ Harga } & \multirow[t]{2}{*}{ Nilai } & \multirow[t]{2}{*}{ Persentase } \\
\hline & Biaya Tunai & & & & \\
\hline 1 & Benih & 88 & 23.000 & 2.024 .000 & 2,74 \\
\hline 2 & Pupuk kandang(kg) & 7621 & 1.500 & 11.431 .500 & 15,50 \\
\hline 3 & Pupuk NPK (kg) & 309 & 3.250 & 1.004 .250 & 1,36 \\
\hline 4 & Pupuk SP-36 & 231 & 2.200 & 508.200 & 0,69 \\
\hline 5 & Pupuk KCL (Kg) & 262 & 2.500 & 655.000 & 0,89 \\
\hline \multirow[t]{7}{*}{6} & Pestisida (Liter) & & & & \\
\hline & Winder & 6,9 & 170.000 & 1.173 .000 & 1,59 \\
\hline & Curacron & 9,8 & 135.000 & 1.323 .000 & 1,79 \\
\hline & Lanet & 5,9 & 175.000 & 1.032 .500 & 1,40 \\
\hline & Decis & 12,9 & 165.000 & 2.128 .500 & 2,89 \\
\hline & Pelengket & 8 & 35.000 & 280.000 & 0,38 \\
\hline & Cymbush & 8,5 & 220.000 & 1.870 .000 & 2,54 \\
\hline \multirow[t]{6}{*}{7} & Nutrisi (Liter) & & & & \\
\hline & Gandasil B & 8,9 & 40.000 & 356.000 & 0,48 \\
\hline & Gandasil D & 6,5 & 45.000 & 292.500 & 0,40 \\
\hline & Supergo & 10,8 & 50.000 & 540.000 & 0,73 \\
\hline & Atonik & 6,5 & 150.000 & 975.000 & 1,32 \\
\hline & Bayfolan & 9,3 & 75.000 & 697.500 & 0,95 \\
\hline \multirow[t]{2}{*}{8} & Tenaga kerja luar & 1198 & 25.000 & 29.950 .000 & 40,60 \\
\hline & Keluarga (HOK) & & & & \\
\hline 9 & Sewa lahan & & & 553.333 & 0,75 \\
\hline 10 & Turus (Batang) & 17.027 & 500 & 8.513 .500 & 11,54 \\
\hline 11 & Tali rafia (Gulung) & 22 & 35.000 & 770.000 & 1,04 \\
\hline 12 & Polybag $(\mathrm{kg})$ & 60 & 40.000 & 2.400 .000 & 3,25 \\
\hline 13 & Karung (buah) & 226 & 3.000 & 678.000 & 0,92 \\
\hline \multirow[t]{2}{*}{14} & Pajak Lahan & & & 426.667 & 0,58 \\
\hline & Jumlah Total Biaya & & & 69.582.450 & \\
\hline B & Biaya Diperhitungkar & & & & \\
\hline \multirow[t]{2}{*}{1} & Tenaga kerja dalam & 165 & 25.000 & 4.125 .000 & 5,59 \\
\hline & Keluarga (HOK) & & & & \\
\hline \multirow[t]{3}{*}{2} & Penyusutan Peralatan & & & 57.700 & 0,08 \\
\hline & Jumlah Total Biaya & & & & \\
\hline & Diperhitungkan & & & & \\
\hline \multirow[t]{2}{*}{$\mathrm{C}$} & Jumlah Total Biaya & itungkan & & 4.182 .700 & \\
\hline & Jumlah Total Biaya & & & 73.765 .150 & 100 \\
\hline
\end{tabular}

Sumber: Analisis Data Primer (2020)

Usahatani cabai rawit merah menggunakan pupuk kandang dan pupuk kimia, penggunaan pupuk kandang untuk penamabahan unsur hara, mengurangi kerusakan tanah, dan untuk memperbaiki struktur organik tanah yang sudah hilang 
akibat penggunaan lahan sebelumnya. Penggunaan pupuk kandang pada penelitian ini rata-rata sebesar 7.621 per kilogram per ha, sehingga total biaya yang dikeluarkan sebesar Rp 11.431.500 atau 15,50 persen dari total biaya pengeluaran.

Pupuk kimia yang digunakan pada budidaya cabai rawit menggunakan tiga pupuk kimia yaitu NPK, SP36, dan Kcl, jika dilihat berdasarkan biaya total pupuk NPK yang digunakan petani responden berada pada rata-rata 1,36 persen sedangakan untuk pupuk SP36 dan KCL sebesar 0,69 dan 0,89 persen.

Pestisida digunakan untuk mencegah hama dan penyakit, berdasarkan hasil wawancara di lapangan pestisida yang digunakan adalah pestisida cair, jumlah rata-rata pestisida yang digunakan petani responden adalah 52 liter per hektar, dengan total biaya yang dikeluarkan sebesar Rp 7.807.000 atau sekitar 10,58 persen dari total biaya seluruhnya.

Penggunaan nutrisi berguna untuk merangsang sel-sel sehingga mampu bekerja lebih giat dalam menyerap unsur hara, jumlah rata-rata nutrisi yang digunakan petani responden sebesar 42 liter per hektar, dengan total biaya yang dikeluarkan sebesar $\mathrm{Rp} 2.861 .000$ atau sebesar 3,88 persen dari total biaya seluruhnya.

Tenaga kerja merupakan faktor penting dalam kegiatan budidaya cabai rawit. Ketersediaan tenaga kerja yang terampil sangat mempengaruhi keberhasilan produksi. Tenaga kerja dalam hal ini adalah petani yang sangat berperan dalam setiap kegiatan usahatani cabai rawit yang diusahakannya. produktivitas juga dipengaruhi oleh keahlian tenaga kerja yaitu petani sendiri. Sering sekali petani mengandalkan pengetahuannya sendiri dalam memproduksi cabai rawit, karena menganggap pengalamannya dalam bertani sudah cukup. Sehingga temuan atau informasi terbaru dari berbagai pihak seperti dari dinas pertanian terkait peningkatan produktivitas cabai kurang diperhatikan. Tenaga kerja yang digunakan dalam usahatani cabai rawit terdiri dari tenagakerja dalam keluarga dan tenaga kerja dari luar keluarga, ratarata upah tenaga kerja yang dikeluarkan oleh petani responden adalah sebesar Rp 25.000 per HOK (hari orang kerja). Tenaga kerja luar keluarga yang digunakan sebesar 40,60 persen sedangkan tenaga kerja dalam keluarga hanya 5,59 persen dari total biaya. 
Perbedaan penggunaan tenaga kerja dapat dilihat pada Tabel 3.

Tabel 3. Penggunaan TKDK dan TKLK dalam usaha tani cabai rawit

\begin{tabular}{lccc}
\hline Uraian & $\begin{array}{l}\text { Jumlah } \\
(\mathrm{HOK})\end{array}$ & Nilai (Rp) & $\%$ \\
\hline $\begin{array}{l}\text { Tenaga kerja } \\
\text { luar keluarga }\end{array}$ & 1.198 & 29.950 .000 & 88 \\
$\begin{array}{l}\text { Tenaga kerja } \\
\text { keluarga }\end{array}$ & 165 & 4.125 .000 & 12 \\
$\begin{array}{l}\text { Total tenaga } \\
\text { kerja }\end{array}$ & 1.363 & 34.075 .000 & 100 \\
\hline \multicolumn{4}{l}{ Sumber: diolah (2020) }
\end{tabular}

Lahan yang digunakan pada usahatani cabai rawit ini adalah lahan milik sendiri dan lahan sewa, lahan sewa mengeluarkan biaya pada komponen biaya tunai. Biaya yang dikeluarkan dalam menyewa lahan adalah $\mathrm{Rp}$ 16.600.000 dengan persentase 0,75 persen dari total biaya.

Turus atau batang yang digunakan pada usahatani cabai rawit, berfungsi agar tanaman tetap tegak pada saat rawan angin kencang, rata-rata penggunaan turus perhektar sebanyak 17.027 dengan persentase 11,54 persen dari total biaya.

Tali raffia digunakan pada saat pembuatan bedengan sebagai patokan agar bedengan rapih, rata-rata penggunaan tali raffia adalah 22 gulung per hektar dengan persentase 1,04 persen dari total biaya. Sedangkan penggunaan polybag dilakukan saat persemain dimana membeli polybag dengan ukuran per kilogram. Adapun rata-rata penggunaan polybag sebanyak 60 kilogram dengan persentase 3,25 persen dari biaya total.

Hasil panen yang diperoleh biasanya dikemas dengan karung, maka rata-rata penggunaan karung perhektar adalah 226 unit, dengan rata-rata biaya yang dikeluarkan oleh petani per hektar adalah Rp 678.000 atau 0,92 persen dari biaya total.

Penggunaan alat-alat pertanian dalam proses produksi tanaman cabai dimaksudkan untuk memudahkan petani dalam melakukan usaha taninya. Biaya yang dikeluarkan untuk alat-alat pertanian berdasarkan nilai penyusutan peralatan yang digunakan setiap tahun. Biaya penyusutan adalah selisih antara harga beli dan harga jual saat dibagi dengan lama penggunaan alat tersebut rata-rata biaya penyusutan peralatan sebesar Rp 57.700 atau 0,08 persen dari toal biay yang dikeluarkan. Data dapat dilihat pada Tabel 4.

Tabel 4. Penyusutan Alat Pertanian

\begin{tabular}{rlrrrrr}
\hline No & $\begin{array}{l}\text { Nama } \\
\text { Alat }\end{array}$ & Jum & harga & $\begin{array}{l}\text { total } \\
\text { biaya }\end{array}$ & umur & penyusutan \\
\hline 1 & Cangkul & 3 & 65000 & 195000 & 4 & 48.750 \\
2 & Kored & 4 & 35000 & 140000 & 4 & 35.000 \\
3 & Sprayer & 2 & 320000 & 640000 & 5 & 128.000 \\
4 & Ember & 10 & 12000 & 120000 & 3 & 40.000 \\
5 & Garpu & 3 & 49000 & 147000 & 4 & 36750 \\
\hline \multicolumn{7}{c}{ Sumber: Data primer $(2020)$} \\
\end{tabular}

Sumber: Data primer (2020)

Pendapatan merupakan salah satu indikator keberhasilan kegiatan usaha tani. Pendapatan usahatani juga 
memberikan gambaran mengenai keuntungan dari kegiatan usahatani. Pendapatan usahatani cabai rawit pada penelitian ini berasal dari selisih antara penerimaan dengan biaya yang dikeluarkan. Analisis pendapatan dapat dibedakan berdasarkan biaya yang dikeluarkan yaitu pendapatan atas biaya tunai dan pendapatan atas biaya total. Berdasarkan hasil analisis usahatani, penerimaan yang diperoleh pada penelitian kali ini adalah sebesar $\mathrm{Rp}$ 130.733.510, biaya tunai yang diperoleh adalah Rp 69.582 .450 dan biaya total sebesar Rp 73.765.150, sedangkan pendapatan atas biaya tunai sebesar $\mathrm{Rp}$ 61.151 .060 dan pendapatan atas biaya total sebesar Rp 56.968.360. data dapat dilihat pada table 5 .

Tabel 5. Rata-rata efisiensi dan pendapatan Cabai rawit di Kec.Cigalontang

\begin{tabular}{clc}
\hline No & \multicolumn{1}{c}{ Uraian } & $\begin{array}{c}\text { Per ha } \\
\text { Rp }\end{array}$ \\
\hline 1 & Penerimaan usahatani & 130.733 .510 \\
2 & Biaya usahatani tunai & 69.582 .450 \\
3 & Biaya usahatani total & 73.765 .150 \\
4 & Pendapatan biaya tunai & 61.151 .060 \\
5 & Pendapatan biaya total & 56.968 .360 \\
6 & Efisiensi (R/C) tunai & 1,88 \\
7 & Efisiensi (R/C) total & 1,77 \\
\hline
\end{tabular}

Sumber: Data primer (2020)

Efisiensi usahatani cabai rawit ditunjukkan dengan nilai $\mathrm{R} / \mathrm{C}$ rasio, nilai $\mathrm{R} / \mathrm{C}$ atas biaya tunai dan biaya biaya total pada penelitian ini dapat dikatakan layak untuk diusahakan karena nilai $\mathrm{R} / \mathrm{C}$ atas kedua pengelompokan biaya tersebut lebih besar dari satu. Nilai R/C atas biaya tunai sebesar Rp 1,88 dan yang berarti setiap satu rupiah biaya yang dikeluarkan dalam usahatani cabai rawit akan diperoleh penerimaan sebesar $\mathrm{Rp} 1,88$ rupiah.

$\mathrm{R} / \mathrm{C}$ atas biaya total sebesar $\mathrm{Rp}$ 1,77 yang berarti setiap pengeluaran biaya satu rupiah maka akan diperoleh tambahan sebesar Rp 1,77. Nilai R/C pada biaya tunai lebih tinggi dari $\mathrm{R} / \mathrm{C}$ biaya total hal ini dikarenakan biaya total terdiri atas biaya tunai dan biaya yang diperhitungkan.

Berdasarkan hasil penelitian terdahulu yang secara umum menunjukkan bahwa sayuran umumnya komoditas cabai menguntungkan bagi petani. Sama halnya dengan yang telah dilakukan siregar (2011) tentang analisis pendapatan usahatani cabai kriting di Desa Citapen secara umum dikatakan menguntungkan dan layak untuk diusahakan dimana keuntungan rata-rata sebesar Rp 86.863.853 dan R/C sebesar 2,65. Adapun penelitian menurut Sholiah (2017) menunjukkan pendapatan usahatani cabai merah di Kecamatan Kedondong sebesar Rp 21.790.275,34 
$\mathrm{kg} / \mathrm{ha}$ dengan nilai $\mathrm{R} / \mathrm{C}$ bernilai 1,98 , artinya usahatani cabai merah yang dilakukan petani secara ekonomi menguntungkan. Hal ini sejalan dengan penelitian yang dilakukan oleh peneliti dimana usahatani cabai rawit di Kecamatan Cigalontang Kabupaten Tasikmalaya layak untuk dikembangkan dan memberikan keuntungan untuk para petani karna $\mathrm{R} / \mathrm{C}>1$. Dengan demikian tingkat pendapatan bersih rata-rata petani cabai di Kecamatan Cigalontang Kabupaten Tasikmalaya per satu kali musim panen sebesar Rp 56.968.360.

\section{KESIMPULAN DAN SARAN}

Rata-rata penerimaan usahatani di Kecamatan Cigalontang adalah Rp $130.733 .510 / \mathrm{ha} /$ th dan biaya usahatani yang terdiri dari biaya tunai sebesar $\mathrm{Rp}$ 69.582.450/ha/th, dan biaya total sebesar $\mathrm{Rp}$ 73.765.150. Usahatani cabai rawit secara umum dikatakan menguntungkan hal ini dapat dilihat ditunjukan dari pendapatan/ keuntungan bersih rata-rata sebesar Rp 61.151.060.
Nilai efisiensi usahatani cabai rawit, nilai $\mathrm{R} / \mathrm{C}$ dari biaya tunai dan biaya total menunjukkan nilai sebesar 1,88 dan 1,77 , yang berarti bahwa penerimaan yang diperoleh dapat menutupi biaya usahatani yang dikeluarkan. Sehingga. menunjukkan bahwa usahatani cabai rawit di Kecamatan Cigalontang layak untuk diusahakan.

\section{DAFTAR PUSTAKA}

BPS Indonesia. Data Harga Cabai Nasional. https://www.bps.go.id diakses 04 Juli 20.

Departemen Pertanian (Deptan). (2012). Sub Sektor Pertanian. Departemen Pertanian. Jakarta.

Cahyono, D. (2003). Cabai Rawit Teknik Budidaya dan Analisis Usahatani. Yogyakarta: Kanisius

Kouassi CK, Koffi-nevry R, Guillaume LY et al. (2012). Profiles of bioactive compounds of some pepper fruit (Capsicum L.) Varieties grown in Côte d'ivoire. Innovative Romanian Food Biotechnol 11: 23-31.

Kustiari, T., D. Susanto, Sumardjo dan I. Pulungan. (2006). Faktor-faktor penentu tingkat kemampuan petani dalam mengelola lahan marjinal. Jurnal Penyuluhan IPB. 2(1): 7-16.

Rahim, A., dan Hastuti D.R.D. (2008). Pengantar, Teori, dan Kasus Ekonomika Pertanian. PS. Jakarta 